\title{
UN-BANKING IN UNDER-DEVELOPING ECONOMY
}

\author{
Babar Ansari \\ M. phill Scholar at Institute of Business Management-IOBM \\ Kanwal Gul \\ M. phill Scholar at Institute of Business Management-IOBM \\ Aamir Feroz Shamsi \\ Professor PAF-KIET \\ Nawaz Ahmad \\ Institute of Business Management-IOBM
}

\begin{abstract}
This research is an attempt to examine the reasons behind un- banking in under developing economy particularly in Pakistan. For this purpose, qualitative approach called summative content analysis approach is used and 36 interviews with banked, under banked and unbanked populace are incorporated.

The study finds that lack of education, trust on bank/banker, volatile situation in city/country, accessibility/convenience, infrastructure, interest rate in terms of religious exclusion and financial benefits, high cost associated with opening and maintaining an account, lack of facility of online payment via debit card/ATM, lack of money, unemployment, government regulations, branch banking, convenience and some other factors are the general reasons for un-banking in Pakistan. However, the study concludes that main factors; convenience, cost and security are the major reasons for un-banking in Pakistan.

After concluding this research authors suggested financial institutions should increase number of access points/centres. Give more authorisations to financial centres, and Promote financial awareness.
\end{abstract}

KEYWORDS: Summative Content Analysis,Unbanked, Security, poverty, financial institution, Cost.

\section{Jel Classification:H41, L31, L21}

*The material presented by the author does not necessarily portray the view point of the editors and the management of the Ilma University - Formerly IBT

1. Babar Ansari: baabaransari@gmail.com

2. Kanwal Gul: kanwal.gul@iobm.edu.pk

3. Aamir Feroz Shamsi: aamir.shamsi@ @afkiet.edu.pk

4. Nawaz Ahmad: nawaz.ahmad@iobm.edu.pk

CILMA-JBS is published by the Ilma University - Formerly IBT

Main Ibrahim Hydri Road, Korangi Creek, Karachi-75190, Pakistan. 


\section{INTRODUCTION}

\subsection{Background}

Financial institutions always remain an important and critical factor in poverty reduction and for prosperous economic growth. Research shows that when people use financial institutions, it is evident that they are in better position to start and grow their businesses, spend in education, better in handling risks, job creation and are in better position to absorb financial shocks.

By having bank accounts, it helps individuals in increasing savings, boost industrious investment and consumption which ultimately benefit the economy as a whole. How many people use bank accounts is a question that hits globally. From developed to developing and underdeveloped countries, research shows majority of the population do not have bank accounts. Worldwide, approximately 2.5 billion people do not have a formal account at financial institutions (The world bank, 2012). Access to affordable financial services is linked to overcoming poverty, reducing income disparities, and increasing economic growth.

According to a study published by the World Bank, in Africa less than a quarter of all adults make use of bank accounts or other financial products from a formal financial institution and $90 \%$ of all consumer payments are conducted with cash. Africa is the world's second largest and second most populous continent, with 1 billion people spread across 56 countries it is difficult to make any statements that will apply uniformly ( Klapper \& Demirgüç-Kunt, Financial Inclusion in Africa: An Overview, 2013). While overall, 23\% of adults in the Africa region have a bank account. Within Africa, there is a large variation in account ownership: $24 \%$ of adults in Sub-Saharan Africa report having an account at a formal financial institution, though this ranges from $51 \%$ in Southern Africa to $11 \%$ in Central Africa in the Democratic Republic of Congo and Central African Republic, more than $95 \%$ of adults are unbanked. (I.e. do not have an account at a formal financial institution) (Leora , 2014). In North Africa $20 \%$ of adults have an account at a formal financial institution ranging from $39 \%$ in Morocco to $10 \%$ in Egypt. One of the main reasons for this large unbanked population in Africa is geographical inaccessibility and poor infrastructure, with many of the unbanked living in remote rural areas. This, combined with the high cost of banking services and a lack of financial education and understanding, creates very high barriers to banking for poor rural populations ( Klapper \& Demirgüç-Kunt, Financial Inclusion in Africa: An Overview, 2013). There is therefore an undeniable benefit for large enterprises to invest some time in understanding the significance of financial inclusion and the practices and tools that can improve growth in baking sector. This sector does however represent a market that is underserved, one that could prove profitable if banks can tap into it and this large unbanked population is no longer going unnoticed. Many banks and financial institutions are seeing the potential in reaching out to the unbanked population as they are the last great untapped market in banking. With the growing consumer market in Africa and the increased penetration of mobile phones and internet access fostering economic drive and entrepreneurship, demand for retail banking is likely to increase substantially, but accessing the widely dispersed population is a challenge that any bank who wishes to access this market will have to overcome.

\subsubsection{Banking in developed countries}

Literature explains that majority of banking services are used by developed countries while underdeveloped countries with fragile economy are bared to use banking services. 
Gallop survey report says from 148 countries, 50 percent of adult (employed/ self-employed) yet to have access to financial inclusion (Gallop Survey, 2011) However, in this regard, a glaring difference emerged among economically rich countries having only 10 percent of unbanked population and middle income developing economies like North African and Middle Eastern countries where only 18 percent of the adult population has access to formal banking services (Khatoon, 2012). But there is a positive side showed by the literature that is according to an article "Financial Inclusion For Asia`s Unbanked" by Veronique with reference of Asian Development Outlook 2015, Asian developing economies will grow with a continuous pace of $6.3 \%$ per year of their GDP. This article also explains that in underdeveloped economies only $27 \%$ of adults have bank accounts; also it highlights the rate of loaning in underdeveloped economies that is only $33 \%$. On one side, underdeveloped countries grow with a continuous pace of $6.7 \%$ of their GDP, while having bank accounts to only $27 \%$ of adults provide an opportunity to capture the untapped market (Asian Development Bank, 2014).

Three fourth of the world's poor do not have bank accounts. The reason is not only poverty but several different reasons that are cost, travel distance and also paper work for opening an account (Klapper, Why are 75\% of the World's Poor Unbanked, 2014). Underdeveloped countries e.g. North African and Middle Eastern countries`18\% adults only have access to banking services. The article also referred South Asian countries which on common 38\% adults' has access to banking services which is far good than North African Countries. In underdeveloped countries with low income bracket, only $22 \%$ adults have access to banking services (Khatoon, 2012) .

\subsubsection{Banking in developing countries}

Developing countries are also victim of unbanking. Facts show that low income people are the one who mostly are unbanked. According to FDIC data (2012) among households with low income level less than $\$ 15000$ per year, $28 \%$ of them have no bank accounts, and $22 \%$ of them have less access to banking services. The research also states that most unbanked people are who are unemployed (Osaki \& Burhouse, 2011). More than 40\% of the population of developing countries are without bank account (Leora, 2014).

Looking at the background of unbanking in Undeveloped Economy, there is still a huge gap is found in banking industry, which is very much essential to be taped for the economic reason of developing countries via different strategies to attract pool towards banking services.

\subsubsection{Banking in Pakistan}

Statistics Show that only $2.9 \%$ Pakistan`s youth use debit cards and only $1 \%$ of them only use debit cards to make payments online or at point of sale (POS) (Shiekh, 2016). Statistics also show that $1.4 \%$ of Pakistan`s youth use bank accounts to receive their salary and $1.8 \%$ of youth use it for government grants/transfers/payments. In Pakistan $6 \%$ of youth have mobile accounts whereas overall South Asia have lower figure of 2.6\% (Pasha, 2016).

For online payment in Pakistan, most of the people use to borrow credit cards from their relatives and friends which is still a difficult task. Statistics show that only $14 \%$ people in Pakistan have debit/credit cards. Majority of them use prepaid cards/debit cards for their payments and cash withdrawals, which are used by two major segments that are Government 
cash transfers i.e. Benazir Income Support Programme cards and Middle class people use for their payments and cash withdrawals through ATMs (Shiekh, 2016).

Comparing Pakistan with other countries, Pakistan is lowest in banked population. As in Pakistan only $7 \%$ out of $40 \%$ of poor population have bank accounts, whereas in Bangladesh, $31 \%$ of $40 \%$ poorest youth have bank accounts, in India, $53 \%$ of youth have bank accounts, whereas in Srilanka, 83\% of the youth have bank accounts (Asian Development Bank, 2014).

Bank account Holders in Pakistan
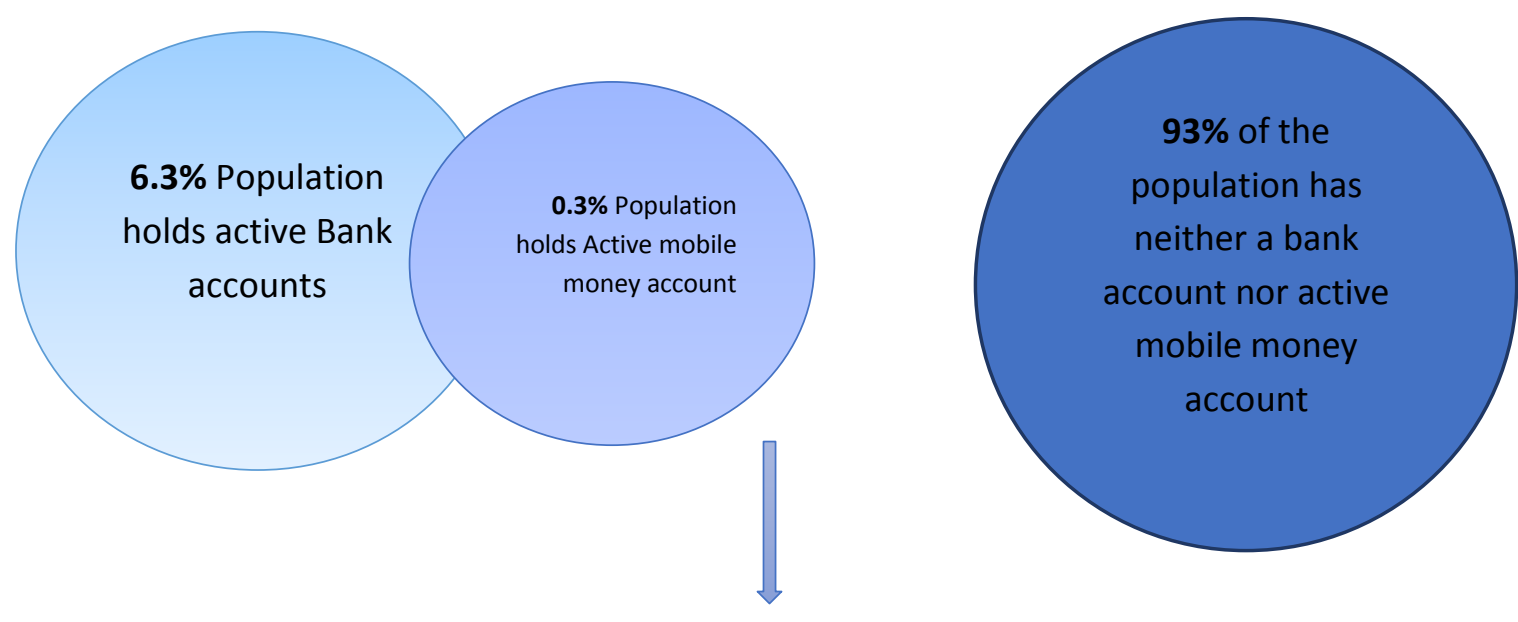

$0.1 \%$ Both

Source: InterMedia Pakistan FII Tracker survey (N=6,000, 15+) November 2013-January 2014

\subsection{Problem Statement}

(Leora Klapper: 2016) research on world financial inclusion suggest that $1 / 3$ of the total world's population is unbaked due to poverty, cost, paper work, accessibility and few other reasons. The researchers are trying to determine whether there are same reasons responsible for un-banking in Pakistan or some other reasons. Besides this, what can be done to increase banking in this part of the world. Financial inclusion can reduce poverty and is helpful in realizing economic growth. There are emerging chances that financial inclusion has significant benefits for individuals. As studies show that when people contribute in financial system, people can invest in education, increase business, control risk and engross financial shocks.

Using both ontological and epistemological phenomenon; the problem statement of this study is, to determine the factors responsible of un-banking, they are in line with the literature and common in Pakistan and in other parts of the world. 


\subsection{Research Objective}

The purpose of our research is to find out the main reasons which lead to the nonusage of financial institutions by the masses of Pakistan.

\subsection{Scope of the Study}

Subsequently it is difficult to gather all data on a matter and reconnoitre every aspect of a matter. This research is also narrow in its scope. It is limited to Pakistani context and in Pakistan also limited to a single province Sindh. However 50 interviews were conducted in the study from several cities of Sindh province. So the study may generalize the total population of Sindh province of Pakistan.

\subsection{Significance of the Study}

This study will weigh its importance in financial sector, educational sector and to individuals as well. Ultimately, it will benefit the banking industry specifically in Pakistan. It will help to suggest the future recommendations to the banking sectors, which they can use them to make people choose banks for financial inclusion (such as Saving, Transactions or Business).

\subsection{Assumptions of the Study}

The authors of the study assume that the factors i.e. Low income level, lack of accessibility, low interest rate, Lack of trust in financial institution, illiteracy, Sharia grouping are the factors that are the reasons people are not using financial institutions in Pakistan. The authors also assume that if the study quantifies these independent variables, financial sector can be able to predict the chief reasons which will help to know about people`s less motivation towards them.

\section{LITERATURE REVIEW}

The goal of any economic system is economic growth. The focus of this research article is to investigate in transition countries whether the financial institutions play any role in supporting the economic growth. In transition countries, banking sector is ruled among all financial intermediaries. The research conducted in South Eastern Europe concluded that interest margin and credits provided to private sector has a negative impact whereas ratio of quasi money has a positive impact in growth of economy. The findings were allusive for policy makers of bank which can encourage more opponents in market, improvement in institutional services and continuous efficiency in risk management ( Kjosevski \& Petkovskia, 2013). Another research article concludes that in any nation, economy and its financial institutions play an important role, as the financial sector of a country becomes more developed the nation grows (Levine 2003). Firms began to expand their reach towards external goods and capitals to expand and prosper when the countries had more established financial institution. A strong positive relationship is found between economic growth in a long-run and development of financial institutions. Formation of capital, enriched productivity and future growth of economy has a positive impact when the economic and political aspects of nations are under control. 
A survey suggested that in developing countries $28 \%$ as more adults are banked than in developed countries (chaia, 2009). While research was conducted in Sub-Saharan Africa where only $16 \%$ people are banked, rest are unbanked due to lack of accessibility in rural areas of Kenya, Uganda and Malawi. Lack of accessibility of a bank can create numerous inconveniences in lives of people. Unbanked people are less likely to save money for future emergencies in consequences they have to take risky and costlier actions like giving away high-yielding animals or selling inventory to survive out of situation. They may engage themselves in activities of profit gain which entail health risks. Now question arises how to achieve financial inclusion. This particular accessibility area have been explored and polished in last few years. Few Innovations account for either reducing barriers for opening an account (low fees) or bringing banks geographically nearer to people ( Jonat, Keats, Green, \& Dupas, 2012). In Brazil, banking industry innovated tools for accessibility to the bank via using "correspondents" or "agents") (Kumar: 2006, McKinsey and Company: 2010). Also in Pakistan banks are using "agents" by which customers can withdraw and deposit their money via retail shops rather than using banks i.e. Easy Paisa, UBL Omni, Jazz Cash, U-Paisa. In developing countries other factors like poverty and trust factor also influence people to go unbanked.

Another factor which promotes un- banking in developing countries such as Ukraine that has very little trust factor in banks and other institutions. People have very little money to save and they prefer to keep it under mattress. People almost 10 to 15 percentages prefer to keep their savings in form of cash rather than depositing into bank accounts (Coupe, 2009). The study examined in Hungary which shows that low trust factors in financial intermediary. The main reason was their past experience in the nineties during bank crisis when people lost their money. They still had the fear and they are expecting to have same crisis in near future. During financial crisis faced between 2007 and 2008 it is believed that public don't trust on people that have gained excess of money in financial segment. The most important factor to be considered is trust as no physical goods are exchanged when an account is opened. If someone fails to trust any institution then they won't like to be their part.

Muslims particularly Indian Muslims have misperception about riba i.e. interest. Now, Muslims have two alternatives left with them either to accept the principal amount as it is and face loss because the worth of money decreases with the time or accept the interest which is associated with the deposit money. This is against the teachings of Islam and considered to be a major sin and unlawful from Sharia view. This is one of the main reasons Muslim community prefer to keep money under mattress rather than depositing it into banks (Rehman, 2007).

Other snags to have a bank account are, use data of 62 countries from 209 banks and develop latest parameters towards barrier in financial intermediaries especially banks around the globe. The barriers include high fees charge for opening and maintain account, requirement of documents and all paper work that has a negative correlation with outreach (Soleda, Demirguc-Kunt , \& Beck, 2007). These hurdles construct a huge mass of population from using services offered by banks. Non-financial factors for instance freedom of media, the infrastructure of bank and financial depth like right of creditors, enforcement of contract are highly correlated.

A research conducted in Mexico and discovered that more usage of ATMs, bank branching and bank agents can lead economy towards development in numerous parameters ( Love \& Bruhn, 2009). A latest study discloses that families having lower income are interested and 
have desire to save money on the other hand they are not the target market or desired consumers of financial institutions (New American Foundation and MicroSave, the SPINNAKER project). If they are provided with accounts with a promise to deposit some cash on monthly or quarterly basis they fail to do so except for few people (Diaz, J. N., Ledesma, J., Anjana, R., Singh, J., \& Tyler, E, 2011). Barclays' 2010 report, state that “...we have found that the most vulnerable people in society are often those who also have the most limited access to financial services" (Barclays Economist Intelligence Unit-The Economist, 2010) Besides, the underprivileged are willing to save whenever they get chance to do (Jacob \& Karlan, 2011)The hurdles faced by financial inclusion in US and OECD varies in different countries. Elimination in OECD economies must be stated as ".exclusion occurs on grounds or prices, products that are inappropriate to people's needs, and the fact that no one is trying to sell them products" (Maeshall, 2004) (OECD, 2011).

Other factor that can effect financial inclusion is variation in income. As few people enjoy with concentrated money, majority of population are at lower end in the distribution of income. Diminishing or deteriorating earnings might disappoint financial inclusion. A survey conducted in 2005 on 5000 households found that banked and unbanked people have analogous demographics and business profiles and outliers are more educated and wealthy as well. Survey findings suggest that correlation of income with opening a bank account is very low. In decision making for opening a bank account, less than 5\% impact due to money holds. Generally, under banked or unbanked families use to have lower to moderate earnings (Micheal \& Barr, 2002). The main barriers towards the usage of banks and other financial institutes are discussed in his research paper highlighting the parameter of low income. Initially, for low income families' account checking has no economic sense. The customers those are unable to meet minimum balance in account have to pay extraordinary monthly charge for checking accounts. Most of banks charge high fees if the checks are bounced and as a result families with low income have less or no savings at all to face the risk associated with it. In addition they can charge high fees on those services that the consumers might not know about it or used these services. Lastly, financial bodies might not be willing to spend on research and development, knowledge about banking system, its benefits, marketing, training that might be helpful to increase the size of business for low income clients. Many researches and studies has assured that majority of unbanked might become banked if they tailored their markets, products and services to needs and desires of low income people as people are willing to open accounts in bank (Eric, 2016).

Other significant parameter of financial organizations include physical infrastructure. Theoretically, it consists of ATMs, retail branches and others facilities. The transaction expenses of using financial facilities for the individual declines when the infrastructure of any nation expands.

However it is predicted that in near future Smartphone technology will balance the requirement of physical infrastructure in many developed countries. There is an expectation that financial inclusion of people will be increased with there will be more positive macroeconomic conditions like high employment rate or high income. For instance, when income rises people will save more and they will prefer to save money in banks.

Those countries that have more educated people are more likely to engage in financial institutions. (Hogarth \& O'Donnel, 1999). An additional report states, "The largest effects-for being unbanked-were found for income, net worth, education, race/ethnicity, and vehicle ownership" (Lusardi, 2005).In United States it was studied that people having primary 
education has less likely to have bank accounts in any financial institution, whereas people having secondary education has $40 \%$ more accounts ( Klapper \& Demirgüç-Kunt, 2013). In order to calculate the outcome of education, the authors calculated the percentage of people registered in secondary education level. People that are well off have more bank accounts than people with less income (Hogarth, Jeanne, Chris Anguelov, \& Lee, 2005). To calculate the wealth of people GNI (Gross national income per capita) was chosen. Other reasons that came into view among people for not using financial institutions were less income and no or little saving ( Klapper \& Demirgüç-Kunt, 2013).

The population in developed countries were not found using access of properfinancial intermediaries and hence become the main purpose of being unbanked. Literature proposes that there are number of ways and access either by means of bank branches, mobile banking systems, and number of ATMs or bank agents, there is a higher banked population ( (Diaz, J. N., Ledesma, J., Anjana, R., Singh, J., \& Tyler, E, 2011)(The world bank, 2012). Many researches have showed that a major obstruction towards an extremely banked population is transportation ( Love \& Bruhn, 2009). On the contrary, the study discovered that even many inhabited regions stay unbanked (Osaki \& Burhouse, 2011)

The author has defined unbanked to designate various groups of persons who are unable to use banks or any other financial intermediaries to complete their financial transactions (Beard, 2010). These people don't have any type of account either checking or saving. The author has proposed several reasons for becoming unbanked which consist of people's facing financial crisis of banks in past, a bad experience with any bank, unable to understand the system of bank, language problem for migrants and any particular reason to open the bank account. Besides these the main factors identified includes those group of people that have low income either living solely or with families, lack of education especially family running by women or youngers and people who have settled form abroad.

\section{METHODOLOGY}

In this Study authors used a qualitative approach to interpret results. 36 interviews from Karachi, Larkana, Sukkur, Daharki, Hyderabad and Shikarpur with banked, under banked and unbanked populace were recorded. Two sampling methods were chosen, Random Sampling and Convenience sampling due to participant's unresponsive behaviour towards research and financial information interrogations. Sample of this study is an assorted population of bankers, maids, job holders, entrepreneurs, contractors, teachers, students, rickshaw drivers, guards and etc. (Potter \& Levine-Donnerstein, 1999)have discussed about qualitative approach called Content Analysis which is classified in three categories like 
CONVENTIONAL CONTENT ANALYSIS, DIRECT CONTENT ANALYSIS AND SUMMATIVE CONTENT ANALYSIS.

Table No. 1.

\begin{tabular}{|c|c|c|c|}
\hline $\begin{array}{l}\text { Type of Content } \\
\text { Analysis }\end{array}$ & Study Starts With & $\begin{array}{l}\text { Timing of defining } \\
\text { codes and keywords }\end{array}$ & $\begin{array}{l}\text { Source of codes and } \\
\text { keywords }\end{array}$ \\
\hline $\begin{array}{l}\text { Conventional } \\
\text { content analysis }\end{array}$ & Observation & $\begin{array}{l}\text { Codes are defined } \\
\text { during data analysis }\end{array}$ & $\begin{array}{l}\text { Codes are derived } \\
\text { from data }\end{array}$ \\
\hline $\begin{array}{l}\text { Direct } \\
\text { Analysis }\end{array}$ & Theory & $\begin{array}{l}\text { Codes are defined } \\
\text { before and during } \\
\text { data analysis }\end{array}$ & $\begin{array}{l}\text { Codes are derived } \\
\text { from theory or } \\
\text { relevant research } \\
\text { findings }\end{array}$ \\
\hline $\begin{array}{l}\text { Summative Content } \\
\text { Analysis }\end{array}$ & Keywords & $\begin{array}{l}\text { Keywords are } \\
\text { identified before and } \\
\text { during data analysis }\end{array}$ & $\begin{array}{l}\text { Keywords are } \\
\text { derived from interest } \\
\text { of researchers or } \\
\text { review of literature }\end{array}$ \\
\hline
\end{tabular}

(Source: Qualitative health research: 2005)

In this paper Summative Content Analysis approach is used which starts with to quantify the frequency of words used in the content and to understand the contextual meaning of the words and ideas as well as indulgent of contextual use of words. This quantification is an attempt not to infer meaning but, rather, to explore usage. ( NL, NS, \& DR, 2002). "If the analysis stopped at this point, the analysis would be quantitative, focusing on counting the frequency of specific words or content" But this paper used latent content analysis approach as well which is beyond summative approach to qualitative content analysis. Latent content analysis refers to the procedure of interpretation. (See Table No. 1). As summative content analysis is used so categories are defined as follows:

\section{RESULTS AND DISCUSSION}

Table No. 2.

Category

1. Lack of education

2. Trust (on bank or banker)

3. Security (volatile situation of the city/country)

4. Accessibility

5. Infrastructure

6. Interest rate (Religious exclusion )

7. Low interest rates (Financial benefits)

8. High cost of account opening

9. Cost of maintaining an Account

10. Lack of money

11. Unemployment

12. Government Regulations

13. Branch Banking

14. Others

Literature helped to determine categories on the basis of previous texts, authors have interpreted the interviews as description or sense of category is already defined in above table. In Table No. 3, there is analysis of the problems and perceptions of unbanked people 
with category and coding, e.g. Sobia, Lavita, Meena, Rashid said "My income is so less, I am currently unemployed, I don't have sufficient amount to save, I don't earn" categorize a single variable of lack of Income/money for those respondents who are unbanked whereas category like lack of literacy is contented as "I have no idea why people use banks, I am not that literate to understand that why they charge monthly fees and for what, I don't know how to fulfil the formalities like paper work, I don't have knowledge about bank in detail and etc"by few unbanked respondents.

TABLE 3.Latent Content Analysis of Unbanked

\begin{tabular}{|c|c|c|c|c|}
\hline SNo & Variable & Description & Variable Code & Interview Transcript \\
\hline 1 & $\begin{array}{l}\text { 1.Lack of } \\
\text { education } \\
\text { 2.Interest rate } \\
\text { (Religious } \\
\text { exclusion) } \\
\text { 3. Low interest } \\
\text { rates (Financial } \\
\text { benefits) }\end{array}$ & $\begin{array}{l}\text { 1. Lack of } \\
\text { education } \\
\text { regarding, } \\
\text { having no idea } \\
\text { why banking is } \\
\text { used. } \\
2 . \quad \text { Views on } \\
\text { Interest rate in } \\
\text { terms of } \\
\text { religion } \\
3 \text {. Views on } \\
\text { Interest rate in } \\
\text { terms of } \\
\text { financial } \\
\text { benefits }\end{array}$ & $\begin{array}{l}\mathrm{LE}=\text { lack of } \\
\text { education } \\
\mathrm{IR}=\text { Interest rate } \\
\text { (Religious } \\
\text { exclusion) } \\
\mathrm{IF}=\text { Low interest } \\
\text { rates (Financial } \\
\text { benefits) }\end{array}$ & $\begin{array}{l}\text { (Wahab, Aged 38, Fruit } \\
\text { Seller) "I have no idea why } \\
\text { people use banks, one of } \\
\text { my friends told me to make } \\
\text { money (Interest on saving) } \\
\text { they use banks. And I keep } \\
\text { my self aside from } \\
\text { interest." }\end{array}$ \\
\hline 2 & $\begin{array}{l}\text { 1.Lack of } \\
\text { education } \\
\text { 2.High cost of } \\
\text { account opening }\end{array}$ & $\begin{array}{l}\text { 1. Lack of } \\
\text { education } \\
\text { regarding, } \\
\text { having no idea } \\
\text { how banking is } \\
\text { used. } \\
2 . \quad \text { Cost of } \\
\text { account } \\
\text { opening } \\
\text { includes fees } \\
\text { that are charged } \\
\text { by bank for } \\
\text { opening } \\
\text { account. }\end{array}$ & $\begin{array}{l}\text { LE=Lack of } \\
\text { education } \\
\mathrm{CO}=\text { High cost of } \\
\text { account opening }\end{array}$ & $\begin{array}{l}\text { Imran Ali, Tailor, "I used to } \\
\text { save money at home but not } \\
\text { in bank because I am not } \\
\text { that literate to understand } \\
\text { that why they charge } \\
\text { monthly fees and for what". }\end{array}$ \\
\hline 3 & 1.Lack of money & 1. Less income & $\begin{array}{l}\mathrm{LM}=\text { Lack } \\
\text { money }\end{array}$ & $\begin{array}{l}\text { Meena, 33, Maid "I never } \\
\text { felt necessity of having a } \\
\text { bank account because I } \\
\text { don't have sufficient } \\
\text { amount to save in bank. }\end{array}$ \\
\hline 4 & $\begin{array}{l}\text { 1.Lack of money } \\
\text { 2. Lack of } \\
\text { education }\end{array}$ & $\begin{array}{l}\text { 1. Less income } \\
2 . \quad \text { Lack of } \\
\text { education } \\
\text { regarding, }\end{array}$ & $\begin{array}{l}\text { LM=Lack } \\
\text { money } \\
\text { LE=Lack } \\
\text { education }\end{array}$ & $\begin{array}{l}\text { Sobia, Age 25, Maid at } \\
\text { school "My income is so } \\
\text { less that I hardly fulfill the } \\
\text { basic needs that is food and }\end{array}$ \\
\hline
\end{tabular}




\begin{tabular}{|c|c|c|c|c|}
\hline & & $\begin{array}{l}\text { having no idea } \\
\text { why banking is } \\
\text { used. }\end{array}$ & & $\begin{array}{l}\text { water for me and my } \\
\text { children. Banks are for rich } \\
\text { people who has huge } \\
\text { amount of money." }\end{array}$ \\
\hline 5 & $\begin{array}{l}\text { 1.Lack } \\
\text { education }\end{array}$ & $\begin{array}{l}\text { 1. Lack of } \\
\text { education } \\
\text { regarding, } \\
\text { having no idea } \\
\text { why banking is } \\
\text { used. }\end{array}$ & $\begin{array}{l}\mathrm{LE}=\text { Lack } \\
\text { education }\end{array}$ & $\begin{array}{l}\text { Muhammad Jabran, Age } \\
\text { 35, Vegetable seller "I } \\
\text { don't have any knowledge } \\
\text { about banks. My family } \\
\text { lives in a village where they } \\
\text { work on farm. We earn a } \\
\text { good amount we keep our } \\
\text { money at home in our } \\
\text { hiding places as we don't } \\
\text { know about banks." }\end{array}$ \\
\hline 6 & $\begin{array}{l}\text { 1.Lack } \\
\text { education } \\
\text { 2.Illiterate }\end{array}$ & $\begin{array}{l}\text { 1. Lack of } \\
\text { education } \\
\text { regarding, } \\
\text { having no idea } \\
\text { why banking is } \\
\text { used. Illiterate } \\
2 . \quad \text { no } \\
\text { means process } \\
\text { knowledge } \\
\text { about proce at } \\
\text { taken place } \\
\text { bank. }\end{array}$ & $\begin{array}{l}\mathrm{LE}=\mathrm{Lack} \\
\text { education } \\
\mathrm{IL}=\text { Illiterate }\end{array}$ & $\begin{array}{l}\text { Fayyaz, Age } 37 \text {, Guard "I } \\
\text { am illiterate and therefore I } \\
\text { don't know how to fulfill } \\
\text { the formalities like paper } \\
\text { work, doing signature so I } \\
\text { am incapable to put money } \\
\text { in bank. Furthermore I } \\
\text { cannot withdraw money or } \\
\text { deposit money for that I } \\
\text { need someone who has } \\
\text { knowledge, it means } \\
\text { depending on someone } \\
\text { else." }\end{array}$ \\
\hline 7 & 1.Interest rate & $\begin{array}{l}\text { 1. Views on } \\
\text { Interest rate in } \\
\text { terms } \\
\text { religion }\end{array}$ & $\mathrm{IR}=$ interest rate & $\begin{array}{l}\text { Allah Bakhsh, Age } 49 \\
\text { Tailor "My molvi friend } \\
\text { told me that interest is a big } \\
\text { sin and all banking system } \\
\text { have interest whether we } \\
\text { deposit money or we take } \\
\text { loan. I don't want to take or } \\
\text { give interest as it is against } \\
\text { Islamic teaching. Those } \\
\text { banks who claim that they } \\
\text { are working on the Islamic } \\
\text { principles are also using } \\
\text { interest system as said my } \\
\text { molvi." }\end{array}$ \\
\hline 8 & $\begin{array}{l}\text { 1.Unemployment } \\
\text { 2.Lack of money }\end{array}$ & $\begin{array}{l}\text { 1. No job to } \\
\text { keep cash } \\
\text { 2. No excess } \\
\text { money to save } \\
\text { it. }\end{array}$ & $\begin{array}{l}\text { U=unemployment } \\
\text { LM=Lack of } \\
\text { money }\end{array}$ & $\begin{array}{l}\text { Sabeen, Age 19, Student, "I } \\
\text { am currently unemployed } \\
\text { (no proper job) therefore } \\
\text { there is no need for me to } \\
\text { open any account. I give } \\
\text { tuitions and earn a small } \\
\text { amount of money that } \\
\text { fulfills my expense and I } \\
\text { prefer to keep my savings }\end{array}$ \\
\hline
\end{tabular}




\begin{tabular}{|c|c|c|c|c|}
\hline & & & & $\begin{array}{l}\text { to mom rather than I banks } \\
\text { because the saving is so } \\
\text { small in terms of hundreds } \\
\text { and hardly in thousand." }\end{array}$ \\
\hline 9 & $\begin{array}{l}\text { 1. Lack of } \\
\text { education } \\
\text { 2. Interest rate } \\
\text { 3. Trust (on bank } \\
\text { or banker) }\end{array}$ & $\begin{array}{l}\text { 1. Lack of } \\
\text { education } \\
\text { regarding, } \\
\text { having no idea } \\
\text { why banking is } \\
\text { used. } \\
2 . \quad \text { Views on } \\
\text { Interest rate in } \\
\text { terms of } \\
\text { religion. } \\
\text { 3. Fear to lose } \\
\text { money or } \\
\text { money will be } \\
\text { taken away by } \\
\text { banks/bankers }\end{array}$ & $\begin{array}{l}\mathrm{LE}=\mathrm{Lack} \\
\text { education } \\
\mathrm{IR}=\text { interest rate } \\
\mathrm{TB}=\text { Trust on } \\
\text { bank or bankers }\end{array}$ & $\begin{array}{l}\text { Cheryl, Age 33, Maid at } \\
\text { home "I don't have any } \\
\text { good experience or positive } \\
\text { thought about banks. } \\
\text { Bankers steal money from } \\
\text { you with interest and take } \\
\text { your home jewelry and all } \\
\text { savings if you are caught in } \\
\text { debt. Furthermore we have } \\
\text { to pay any fees and over } \\
\text { draft penalties" }\end{array}$ \\
\hline 10 & 1.Interest rate & $\begin{array}{l}\text { 1. Views on } \\
\text { Interest rate in } \\
\text { terms } \\
\text { religion }\end{array}$ & $\mathrm{IR}=$ interest rate & $\begin{array}{l}\text { Sukaina, Age } 34 \text {, teacher "I } \\
\text { get huge amount of money } \\
\text { from my committee and I } \\
\text { buy a block of gold instead } \\
\text { of keeping cash in bank or } \\
\text { keeping money at home. } \\
\text { The block is small so I can } \\
\text { easily hide it in my hiding } \\
\text { place and when I need } \\
\text { money I sell it to get cash at } \\
\text { that time. Keeping cash is } \\
\text { wastage and banks give a } \\
\text { small interest." }\end{array}$ \\
\hline 11 & $\begin{array}{l}\text { 1.Lack of } \\
\text { education } \\
\text { 2. High cost of } \\
\text { account opening }\end{array}$ & $\begin{array}{l}\text { 1. Lack of } \\
\text { education } \\
\text { regarding, } \\
\text { having no idea } \\
\text { why banking is } \\
\text { used. } \\
2 \text {. Cost of } \\
\text { account } \\
\text { opening } \\
\text { includes fees } \\
\text { that are charged } \\
\text { by bank for } \\
\text { opening } \\
\text { account. }\end{array}$ & $\begin{array}{l}\mathrm{LE}=\text { Lack of } \\
\text { education } \\
\mathrm{CO}=\text { cost of } \\
\text { opening account }\end{array}$ & $\begin{array}{l}\text { Baig Ali, Age 48, Auto- } \\
\text { driver "I like to open an } \\
\text { account in any bank if } \\
\text { someone agrees to guide } \\
\text { me because I am illiterate } \\
\text { but I have some savings } \\
\text { with me. I feel afraid to go } \\
\text { to bank on my own and ask } \\
\text { them to open my account as } \\
\text { they will charge me } \\
\text { unnecessarily on keeping } \\
\text { money in account with fees } \\
\text { as it has been faced by one } \\
\text { of my friend." }\end{array}$ \\
\hline 12 & $\begin{array}{l}\text { 1.Lack } \\
\text { education }\end{array}$ & $\begin{array}{l}\text { 1. Lack } \\
\text { education }\end{array}$ & $\begin{array}{l}\mathrm{LE}=\mathrm{Lack} \\
\text { education }\end{array}$ & $\begin{array}{l}\text { Majeed, Age 27, Sweeper"I } \\
\text { am illiterate. I have seen }\end{array}$ \\
\hline
\end{tabular}




\begin{tabular}{|c|c|c|c|c|}
\hline & $\begin{array}{l}\text { 2. High cost of } \\
\text { account opening } \\
\text { 3. High cost of } \\
\text { maintaining the } \\
\text { account. }\end{array}$ & $\begin{array}{l}\text { regarding, } \\
\text { having no idea } \\
\text { why banking is } \\
\text { used. } \\
2 \text {. Cost of } \\
\text { account } \\
\text { opening } \\
\text { includes fees } \\
\text { that are charged } \\
\text { by bank for } \\
\text { opening } \\
\text { account. } \\
3 \text {. Cost of } \\
\text { maintaining } \\
\text { includes zakat } \\
\text { fees, locker } \\
\text { fees and ATM } \\
\text { fees. }\end{array}$ & $\begin{array}{l}\mathrm{CO}=\text { cost of } \\
\text { opening account }\end{array}$ & $\begin{array}{l}\text { banks and I wish to have } \\
\text { my own bank account like } \\
\text { other people but I cannot } \\
\text { open my account as I have } \\
\text { no savings with me. If I } \\
\text { manage to open the } \\
\text { account, I will not be able } \\
\text { to maintain it as the cost } \\
\text { and fees related to it are } \\
\text { high." }\end{array}$ \\
\hline 13 & $\begin{array}{l}\text { 1.Accessibility } \\
\text { 2. Lack of } \\
\text { education }\end{array}$ & $\begin{array}{l}\text { 1. Accessibility } \\
\text { regarding no } \\
\text { banks in remote } \\
\text { areas. } \\
2 . \quad \text { Lack of } \\
\text { education } \\
\text { regarding, } \\
\text { having no idea } \\
\text { why banking is } \\
\text { used. }\end{array}$ & $\begin{array}{l}\mathrm{A}=\text { Accessibility } \\
\mathrm{LE}=\text { Lack of } \\
\text { education }\end{array}$ & $\begin{array}{l}\text { Jameel Khan, Age } 39 \text {, } \\
\text { butcher" My family lives in } \\
\text { remote areas of Balochistan } \\
\text { where there's no excess to } \\
\text { banks and being } \\
\text { uneducated I have never } \\
\text { heard about it." }\end{array}$ \\
\hline 14 & $\begin{array}{l}\text { 1.Lack of } \\
\text { education } \\
\text { 2.Lack of money } \\
\text { 3. No need } \\
\text { required. }\end{array}$ & $\begin{array}{l}\text { 1. Lack of } \\
\text { education } \\
\text { regarding, } \\
\text { having no idea } \\
\text { why banking is } \\
\text { used. } \\
\text { 2. No excess } \\
\text { money to save } \\
\text { it. } \\
\text { 3. Never } \\
\text { thought of } \\
\text { opening an } \\
\text { account. }\end{array}$ & $\begin{array}{l}\text { LE=Lack } \\
\text { education } \\
\text { LM=Lack of } \\
\text { Money } \\
\mathrm{N}=\text { Need for bank }\end{array}$ & $\begin{array}{l}\text { Lavita, Age 37, Housewife } \\
\text { "I am matric pass and } \\
\text { widow. I don't earn rather } \\
\text { than I am dependent on my } \\
\text { brother to fulfill my basic } \\
\text { needs as I have to look after } \\
\text { my small kids. I don't have } \\
\text { knowledge about bank in } \\
\text { detail and I never thought } \\
\text { of opening account." }\end{array}$ \\
\hline 15 & $\begin{array}{l}\text { 1.Security } \\
\text { (volatile situation } \\
\text { of the } \\
\text { city/country) } \\
\text { 2.Accessibility }\end{array}$ & $\begin{array}{l}\text { 1. Threats } \\
\text { related to banks } \\
\text { like robbery. } \\
\text { 2. Accessibility } \\
\text { regarding no } \\
\text { banks in remote } \\
\text { areas. }\end{array}$ & $\begin{array}{l}S=\text { Security } \\
\text { (volatile situation } \\
\text { of the } \\
\text { city/country) } \\
A=\text { Accessibility }\end{array}$ & $\begin{array}{l}\text { Rashid Ali, } 45 \text {, Landlord. "I } \\
\text { don't like to visit bank if } \\
\text { they come to me to for } \\
\text { account opening and other } \\
\text { services Iike open an } \\
\text { account because I belongs } \\
\text { to a village and there is lot } \\
\text { of security threat for a } \\
\text { person who visit bank. }\end{array}$ \\
\hline
\end{tabular}




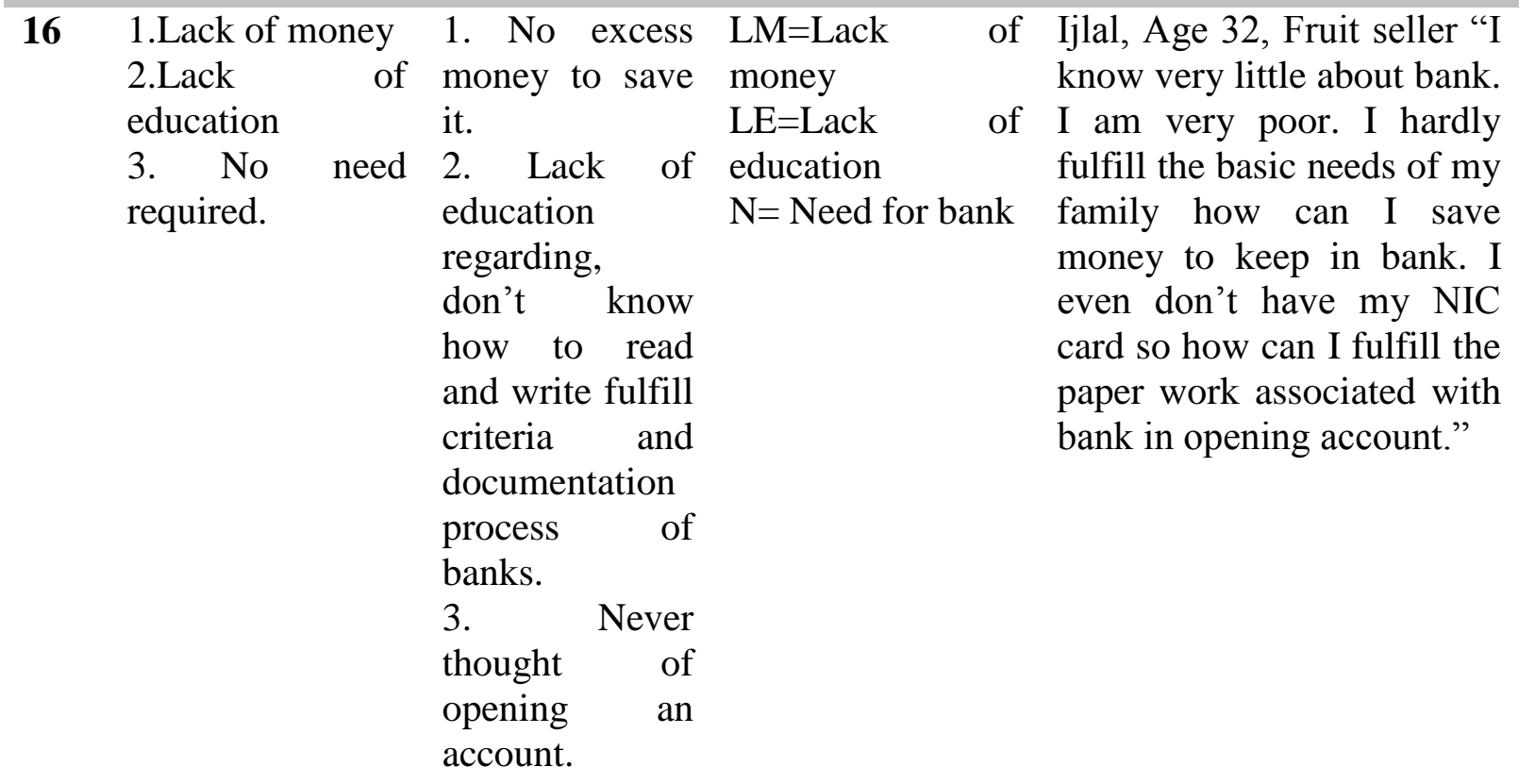

\begin{tabular}{|c|c|c|c|c|}
\hline 17 & $\begin{array}{l}\text { 1.Interest rate } \\
\text { 2.Lack of money } \\
\text { 3. No need } \\
\text { required. }\end{array}$ & 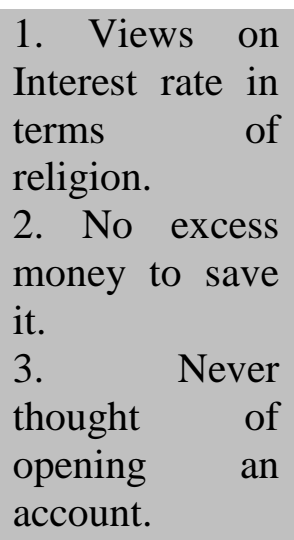 & $\begin{array}{l}\text { IR=interest rate } \\
\mathrm{LM}=\text { Lack of } \\
\text { money } \\
\mathrm{N}=\text { Need for bank }\end{array}$ & $\begin{array}{l}\text { Munawar, Age 30, School } \\
\text { van driver "I am inter-pass, } \\
\text { but I know about bank that } \\
\text { helps to keep money save. I } \\
\text { have never thought of } \\
\text { opening account because of } \\
\text { little savings and interest } \\
\text { system in banks. If I get a } \\
\text { chance I will open my } \\
\text { account in Islamic banks" }\end{array}$ \\
\hline 18 & $\begin{array}{l}\text { 1.Lack of money } \\
2 . \quad \text { Lack of } \\
\text { education }\end{array}$ & $\begin{array}{l}\text { 1. No excess } \\
\text { money to save } \\
\text { it. } \\
2 . \quad \text { Lack of } \\
\text { education } \\
\text { regarding, } \\
\text { don't know } \\
\text { how to read } \\
\text { and write fulfill } \\
\text { criteria and } \\
\text { documentation } \\
\text { process of } \\
\text { banks }\end{array}$ & $\begin{array}{l}\text { LM=Lack } \\
\text { Money } \\
\text { LE=Lack } \\
\text { education }\end{array}$ & $\begin{array}{l}\text { Assia, Age } 34 \text {, chef "I have } \\
\text { to fulfill my house expense } \\
\text { as my mother is severely ill } \\
\text { and there is no one in } \\
\text { family to help us. I have } \\
\text { little knowledge about } \\
\text { banks but they are also not } \\
\text { saving at present. Robbers } \\
\text { even robbed banks taking } \\
\text { all possessions so it's better } \\
\text { to keep money at home." }\end{array}$ \\
\hline
\end{tabular}

Whereas respondents who are under banked, their major concerns remain security and government restriction on financial transactions. 
Table 4: Latent Content Analysis of under banked and banked

\begin{tabular}{|c|c|c|c|c|}
\hline S.No & Variable & Description & Variable Code & Interview Transcript \\
\hline 1 & Others & $\begin{array}{l}1 . \quad \text { Others } \\
\text { including } \\
\text { confusion } \\
\text { between } \\
\text { technical } \\
\text { terms used is } \\
\text { banks }\end{array}$ & $\mathrm{O}=$ Others & $\begin{array}{l}\text { Anonymous, Department } \\
\text { officer, "I never felt } \\
\text { any problems via } \\
\text { maintaining my account } \\
\text { but one thing which } \\
\text { always confuse me that } \\
\text { the terms they use like } \\
\text { Current Acc/Savings } \\
\text { Acc, I usually call } \\
\text { branch when I use ATM } \\
\text { that what should choose } \\
\text { between these options }\end{array}$ \\
\hline 2 & $\begin{array}{l}\text { 1.High cost of } \\
\text { account opening } \\
2 . \quad \text { Cost of } \\
\text { maintaining an } \\
\text { Account }\end{array}$ & $\begin{array}{l}\text { 1. Cost of } \\
\text { account } \\
\text { opening } \\
\text { includes fees } \\
\text { that are } \\
\text { charged by } \\
\text { bank for } \\
\text { opening } \\
\text { account. } \\
\text { 2. Cost of } \\
\text { maintaining } \\
\text { includes } \\
\text { zakat fees, } \\
\text { locker fees } \\
\text { and ATM } \\
\text { fees. }\end{array}$ & $\begin{array}{l}\mathrm{CO}=\text { cost of opening } \\
\text { account } \\
\mathrm{CM}=\text { cost of } \\
\text { maintaining account }\end{array}$ & $\begin{array}{l}\text { Ahmed, Age 46, } \\
\text { Shopkeeper " At present, } \\
\text { I don't have any bank } \\
\text { account but once I } \\
\text { opened my account } \\
\text { because my friend told } \\
\text { me money are placed } \\
\text { save there but after } \\
\text { depositing money my } \\
\text { money was lessen in the } \\
\text { name of zakat charges } \\
\text { and ATM fees so I } \\
\text { withdraw all my money } \\
\text { and now I don't trust } \\
\text { banks. I don't know why } \\
\text { people use bank when } \\
\text { there are so many } \\
\text { deductions." }\end{array}$ \\
\hline 3 & 1.Accessibility & $\begin{array}{l}1 . \\
\text { Accessibility } \\
\text { regarding no } \\
\text { banks in } \\
\text { remote areas. }\end{array}$ & $A=$ Accessibility & $\begin{array}{l}\text { Age } 29 \text {, Student "I am in } \\
\text { Karachi from } 2 \text { years for } \\
\text { perusing my higher } \\
\text { education. I opened an } \\
\text { account } 6 \text { months before } \\
\text { as I don't have any } \\
\text { source of earning so I } \\
\text { use to get my money } \\
\text { transferred from my } \\
\text { village so I opened bank } \\
\text { account to use ATM } \\
\text { service. But in our } \\
\text { village my father always } \\
\text { get upset to transferring } \\
\text { funds because no banks } \\
\text { are available in near }\end{array}$ \\
\hline
\end{tabular}




\begin{tabular}{|c|c|c|c|c|}
\hline & & & & area. \\
\hline 4 & 1.Accessibility & $\begin{array}{l}1 . \\
\text { Accessibility } \\
\text { regarding no } \\
\text { knowledge } \\
\text { about process } \\
\text { taken place in } \\
\text { bank. }\end{array}$ & $\mathrm{A}=$ Accessibility & $\begin{array}{l}\text { Zahid Hussain, Age } \\
\text { 31,Shop keeper " I used } \\
\text { cash transactions but if I } \\
\text { get facilitate that some } \\
\text { one (Banker) come to } \\
\text { me and take my all } \\
\text { information and open an } \\
\text { account then I will prefer } \\
\text { a bank account for } \\
\text { business transactions }\end{array}$ \\
\hline 5 & 1.Interest Rate & $\begin{array}{l}\text { 1. Views on } \\
\text { Interest rate } \\
\text { in terms of } \\
\text { religion. }\end{array}$ & $\mathrm{IR}=$ interest rate & $\begin{array}{l}\text { Anwaar, Age 42, } \\
\text { Shopkeeper " I opened } \\
\text { an account one year ago } \\
\text { but when I came to } \\
\text { know more about Islam } \\
\text { and haram earning by } \\
\text { means of interest for } \\
\text { saving money, I } \\
\text { withdrew all my money. } \\
\text { I can't understand why } \\
\text { Muslims don't follow } \\
\text { their Islamic teachings } \\
\text { and protest against these } \\
\text { banks." }\end{array}$ \\
\hline 6 & $\begin{array}{l}\text { 1. Security(volatile } \\
\text { situation of the } \\
\text { city/country) } \\
\text { 2.Interest rate } \\
\text { (Religious } \\
\text { exclusion) }\end{array}$ & $\begin{array}{l}\text { 1. Threats } \\
\text { related to } \\
\text { banks like } \\
\text { robbery. } \\
2 . \text { Views on } \\
\text { Interest rate } \\
\text { in terms of } \\
\text { religion. }\end{array}$ & $\begin{array}{l}\mathrm{S}=\text { Security(volatile } \\
\text { situation of the } \\
\text { city/country) } \\
\text { IR=Interest rate } \\
\text { (Religious exclusion } \\
\text { ) }\end{array}$ & $\begin{array}{l}\text { Zain Ansari, Business } \\
\text { man "I have two } \\
\text { accounts in bank but I } \\
\text { am not satisfied because } \\
\text { I think its "Haram". But } \\
\text { because of nature of my } \\
\text { business I have to use a } \\
\text { bank account. And } \\
\text { another concerned is that } \\
\text { I have also security } \\
\text { issues because here in } \\
\text { village if people get to } \\
\text { know someone has bank } \\
\text { account that means that } \\
\text { person is sound and } \\
\text { wealthy" }\end{array}$ \\
\hline 7 & $\begin{array}{ll}\text { 1. Cost } & \text { of } \\
\text { maintaining an } \\
\text { Account }\end{array}$ & $\begin{array}{l}\text { 1. Cost of } \\
\text { maintaining } \\
\text { includes } \\
\text { zakat fees, } \\
\text { locker fees } \\
\text { and ATM } \\
\text { fees. }\end{array}$ & $\begin{array}{l}\mathrm{CM}=\text { Cost } \\
\text { maintaining } \\
\text { Account }\end{array}$ & $\begin{array}{l}\text { Kamran Ali, Spare parts } \\
\text { shop "I have } 3 \text { accounts } \\
\text { but I am concerned } \\
\text { about banking charges. } \\
\text { Monthly they use to cut } \\
\text { charges and I don't } \\
\text { understand why and for } \\
\text { what I am paying those } \\
\text { charges" }\end{array}$ \\
\hline
\end{tabular}




\begin{tabular}{|c|c|c|c|c|}
\hline 8 & 1.Branch Banking & $\begin{array}{l}1 . \quad \text { Issues } \\
\text { related to } \\
\text { transferring } \\
\text { of money. }\end{array}$ & $\mathrm{B}=$ Branch Banking & $\begin{array}{l}\text { Shopkeeper "Yes I have } \\
\text { a bank account but in } \\
\text { our village due to } \\
\text { Benazir income support } \\
\text { program we face } \\
\text { problems regarding } \\
\text { ATM machines. We use } \\
\text { to standup in queue for } \\
\text { hours" }\end{array}$ \\
\hline 9 & $\begin{array}{l}\text { 1.Interest rate } \\
\text { (Religious } \\
\text { exclusion ) }\end{array}$ & $\begin{array}{l}\text { 1. Views on } \\
\text { Interest rate } \\
\text { in terms of } \\
\text { religion. }\end{array}$ & $\begin{array}{l}\text { IR=Interest rate } \\
\text { (Religious exclusion } \\
\text { ) }\end{array}$ & $\begin{array}{l}\text { Farhan Ali, Auto agency } \\
\text { " Maintaining } 4 \text { bank } \\
\text { accounts due to business } \\
\text { need but I always } \\
\text { concerned about Riba } \\
\text { which is haram in our } \\
\text { religion so I personally } \\
\text { do not prefer having a } \\
\text { bank account. Beside } \\
\text { that I don't have any } \\
\text { other issues regarding } \\
\text { banking services". }\end{array}$ \\
\hline 10 & $\begin{array}{l}\text { 1.Government } \\
\text { Regulations } \\
\text { 2. Others }\end{array}$ & $\begin{array}{l}\text { 1. Tax issues } \\
2 . \quad \text { Others } \\
\text { including } \\
\text { payments } \\
\text { issues }\end{array}$ & $\begin{array}{l}\text { GR=Government } \\
\text { Regulations } \\
\mathrm{O}=\text { Others }\end{array}$ & $\begin{array}{l}\text { Dharmendar, Rice Miler, } \\
\text { "3-4 accounts I am } \\
\text { maintaining, but due to } \\
\text { government tax } \\
\text { imposition I am reluctant } \\
\text { to operate My accounts. } \\
\text { Besides that if I have to } \\
\text { made any } \\
\text { nationa/International } \\
\text { online payments, } \\
\text { regardless of } \\
\text { Visa/Master Debit cards } \\
\text { I am unable to pay that } \\
\text { also. }\end{array}$ \\
\hline 11 & $\begin{array}{l}\text { 1.Government } \\
\text { Regulations }\end{array}$ & 1. Tax issues & $\begin{array}{l}\text { GR=Government } \\
\text { Regulations }\end{array}$ & $\begin{array}{l}\text { Anees Ahmed Banker in } \\
\text { National Bank "because } \\
\text { of government taxes } \\
\text { frequency of transactions } \\
\text { has been affected (low). }\end{array}$ \\
\hline 12 & $\begin{array}{l}\text { 1. Security(volatile } \\
\text { situation of the } \\
\text { city/country) }\end{array}$ & $\begin{array}{lr}1 . & \text { Threats } \\
\text { related } & \text { to } \\
\text { banks like } \\
\text { robbery. }\end{array}$ & $\begin{array}{l}\mathrm{SC}=\text { Security(volatile } \\
\text { situation of the } \\
\text { city/country) }\end{array}$ & $\begin{array}{l}\text { Bilal, Karachi, } \\
\text { Mechanical engineer "I } \\
\text { have safety issues } \\
\text { because I got mugged } 2 \\
\text { times by using ATM } \\
\text { withdrawal" }\end{array}$ \\
\hline 13 & 1.Others & $\begin{array}{l}\text { 1. Others } \\
\text { include }\end{array}$ & $\mathrm{O}=$ Others & $\begin{array}{l}\text { Parveen, } \quad \text { Housewife } \\
\text { "Sometimes because my }\end{array}$ \\
\hline
\end{tabular}




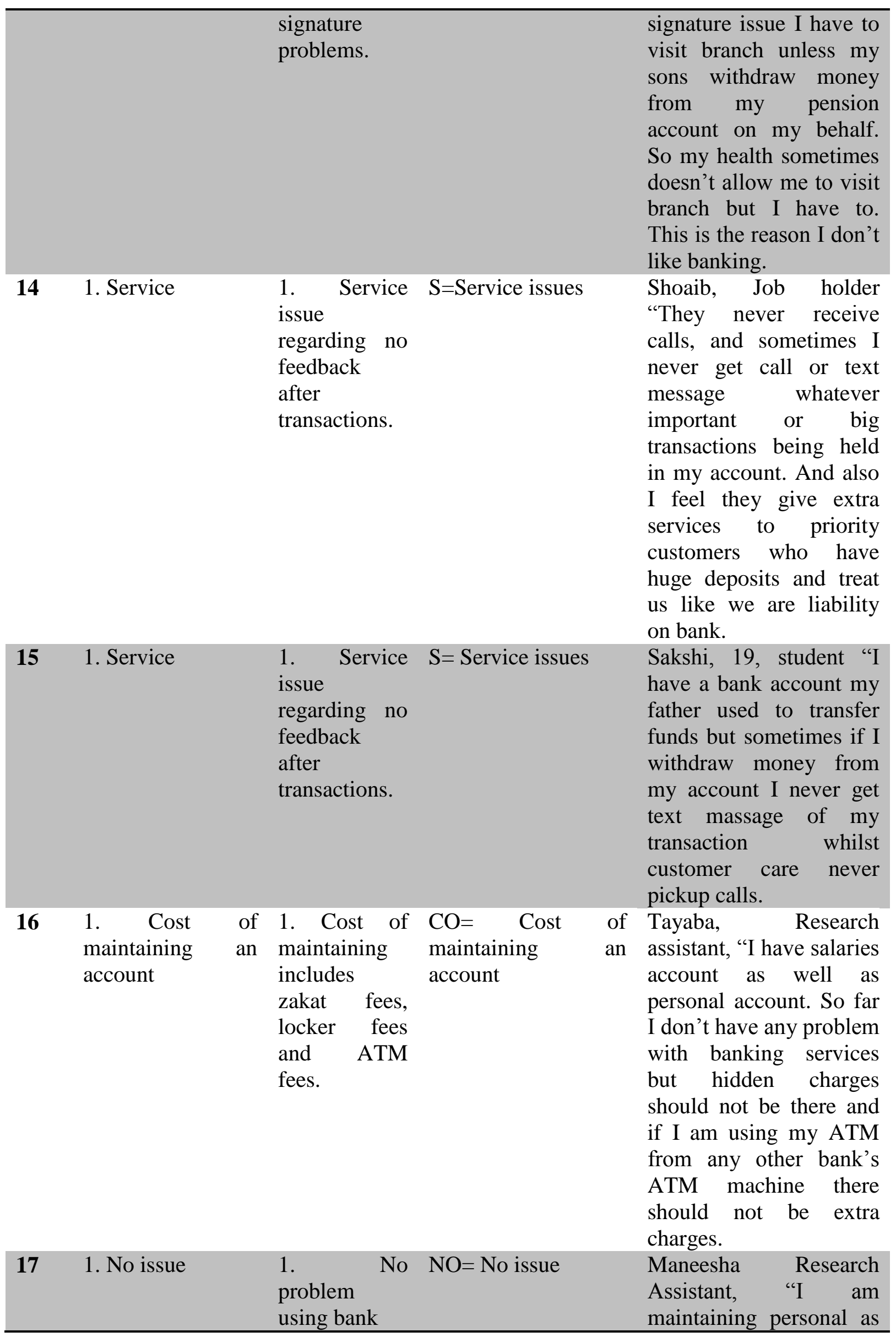




\begin{tabular}{|c|c|c|c|}
\hline & & & $\begin{array}{l}\text { well as salaried account } \\
\text { so far I didn't face any } \\
\text { problem with banking. }\end{array}$ \\
\hline 18 & $\begin{array}{l}\text { 1. Service issues } \\
\text { 2.Security(volatile } \\
\text { situation of the } \\
\text { city/country) }\end{array}$ & $\begin{array}{l}\text { 1. Service } \mathrm{S}=\text { Service } \\
\text { issues related } \mathrm{SC}=\text { Security(volatile } \\
\text { to no safety at } \\
\text { situation of the } \\
\text { ATMs and } \\
\text { others. } \\
2 . \quad \text { Threats } \\
\text { related to } \\
\text { banks like } \\
\text { robbery. }\end{array}$ & $\begin{array}{l}\text { Bilal Khan, Age 29, } \\
\text { Shopkeeper, "I have a } \\
\text { bank account where me } \\
\text { and my brother deposit } \\
\text { money jointly because } \\
\text { we both have little } \\
\text { savings so that we can } \\
\text { get small profit and use } \\
\text { cash when needed. } \\
\text { Keeping money at home } \\
\text { is not save especially } \\
\text { when we are living in } \\
\text { Karachi. I face } \\
\text { problems Inile } \\
\text { withdrawing cash from } \\
\text { ATMs as I have been } \\
\text { robbed twice. Similarly } \\
\text { sometimes I failed to get } \\
\text { my account statement." }\end{array}$ \\
\hline
\end{tabular}

50 interviews were conducted and 36 are incorporated in this study due to word count limitation. But these 36 interviews generalized the whole population of 50 interviews because reimaging 14 interviews were replicating 3 categories of security, literacy rate and accessibility in interior Sindh.

\section{CONCLUSION AND RECOMMENDATIONS}

\subsection{Conclusion}

For most of people having a bank account is as normal as living, but according to (UNESCO), Major population is living below the poverty line having no or little excess to money/savings or they are unemployed. This leads people to supplement bank account with unconventional financial services. In this situation, users go unbanked or under banked."(The unbanked and under banked) are more to be expected to fall victim to the high-rate (predatory) side of the industry, like payday, account-advance, tax refund-advance and structured, settlement-advance loans, to name a few," says Mitchell Weiss, an adjunct professor of finance at the University of Hartford Conn.).

Weiss says classically, the unbanked and under banked be likely to be deprived and operational class individuals who designate to stay away from banks because they either don't have the financial resources to maintain a bank account, or lack knowledge of how the banking system works,. But that's not always the case. In fact, there are few other reasons why some people are unbanked or under banked with respect to country and culture.

Still, South Asian countries like Pakistan show a tremendous growth in the banking industry in the past recent years. Also, State bank of Pakistan have made it compulsory to open at least 
$20 \%$ of bank's branches in rural and unbanked areas of Pakistan. in spite of that authors discovered that lack of convenience in rural areas is another major issue faced by Pakistanis. People living in city are unable to transfer cash to their families living in remote areas as they-living in rural areas- have no access to banks in their towns/villages.

Expansions of commercial bank's branches and micro finance banks have been integrated in rural areas of Pakistan. But respondents from rural Sindh said that they still facing the lack of facility of banks in interior, either they have to go to nearer city or far from their village to operate their accounts. The respondents who have access to bank stated that they are facing service issues as extra services are provided to customers who have huge deposits in bank, people don't get email or message while transactions are carried between accounts and customer care centres don't pick up calls made by customers. The law and order situation of Pakistan also create barriers for the usage of banks as people are getting robbed on ATMs. Despite of bank's ease to open an account with only CNIC, respondents have issue with documentation and cost of operating account, respondents stated that sudden hidden charges are charged from their account without any notification. In rural areas, people used to wait in long queues in the days of Benazir Income Support Programme`s cash disbursements.

Banking are famous for their customer services, as their business is fully dependent on their deposits, despite of that, few respondents have claimed for the poor banking service. With the help of Summative Content Analysis, it determined that customers have to wait long in customer service help lines and in branch banks too. Authors also get responses from senior citizens, in spite of State bank of Pakistan`s hard instructions to banks for senior citizens, respondents claim that sometimes banks ask their personal visits, even they know their kids withdraw their cash/pension amount on their behalf through their signed cheques. The very interesting factor authors found that, Pakistan being an Islamic state, it was assumed that majority of respondents will respond as Interest based banking is Haram and this could be the major reason of going un banked but results were opposite, only two respondents out of fifty have issue with banking with respect to religious limitations.

As authors have identified problems faced by people in Pakistan for banking, this study can be replicated with higher number of respondents who can share their intentions and problems towards banking in Pakistan. Ultimately it will be fruitful for financial sectors to identify and vanish those problems that limit people to have bank accounts. As this study propose the main reasons behind un -banking in Sindh province, it can also help people of Sindh or Pakistan to get educated regarding banking and saving money which ultimately encourage to nourish Pakistan's economy.

\section{$5.2 \quad$ Recommendations}

Financial institution and technology development is hallmark for development in economy. Therefore, financial intermediaries must harness that innovation to meet the needs of low income Pakistanis. It is recommended that the first account initiative is necessary for low and moderate income families that can benefit economy as a whole. The regulatory authorities (SBP), banking sector along with Government can work together to build reforms for the expansion and creating awareness about financial institutions among people. Branchless banking and mobile banking must be spread on large scale to transfer money from urban to rural areas or vice versa across Pakistan.

Other suggestions are: 
1. Marketing and opening of digital/online accounts which will help to access large pool with bulk amounts.

2. Increasing number of access points/centres.

3. Giving more authorisations to financial centres.

4. Promoting financial awareness.

Since there is a great scope of branchless banking in Pakistan therefore following are some steps which can improve branchless banking across Pakistan:

1. . Decrease in cost for private sector to pay their invoices and salaries online.

2. Easy Paisa satisfied 650,000 customers, having 75000 shops in more than 800 cities it can be boost up further.

3. Structuring a legal and secured framework for banking and nonbanking transactions, this ensured the security of branchless banking.

4. Educating public on digital transactions.

In the light of the research findings, people of Pakistan needs education for digital banking with their ease to use and other cost effective benefits, also it will lessen security issues too. Regularity Authority for banking should fix a certain percentage of revenue on banks for marketing in untapped/rural areas of Pakistan, so that maximum customers could reach in banking services.

To secure digital banking, a secured digital framework is to be ensured.

\section{REFERENCES}

Asian Development Bank. (2014). Financial Inclusion in Asia. 2014 Asian Development Bank Institute.

Barclays Economist Intelligence Unit-The Economist. (2010). Banking for Billions: Increasing Access to Financial Services.

Beard, M. P. (2010). Reaching the unbanked and underbanked. Fedral Reserve Bank of St.Louis

chaia. (2009). find a weak relationship between urbanization and financial access.

Coupe, T. (2009). Trust in Banks.

Diaz, J. N., Ledesma, J., Anjana, R., Singh, J., \& Tyler, E. (2011). Saving for the Poor In the Philippines. The New American Foundation and MicroSave.

Eric, P. (2016). How Can Banks Get Away With Charging Such High Fees. Retrieved from www.slate.com

Gallop Survey. (2011). World Bank and Gallop Survey reports of 2011. Retrieved from http://fp.brecorder.com/2012/11/201211071256143

Hogarth, Jeanne, Chris Anguelov, C., \& Lee, J. (2005). Why Don't Households Have a Checking Account. The Journal of Consumer Affairs.

Hogarth, M. J., \& O’Donnel, K. H. (1999). Banking relationships of lower-income families and the governmental trend toward electronic payment. Fedral Reserve Bulletin, 85.

InterMedia Pakistan FII. (2013). InterMedia Pakistan FII Tracker survey $(\mathrm{N}=6,000,15+)$ November 2013-January 2014.

Jacob, \& Karlan, D. (2011). More Than Good Intentions.

Jonat, R., Keats, A., Green, S., \& Dupas, P. (2012, Sep). Challenges in Banking the Rural Poor:Evidence from Kenya's Western Province.

Khatoon, A. (2012, Nov 7). Unbanked population. 
Kjosevski, J., \& Petkovskia, M. (2013). Does banking sector development promote economic growth? An empirical analysis for selected countries in Central and South Eastern Europe. Economic Research-Ekonomska Istraživanja, .

Klapper, L., \& Demirgüç-Kunt, A. (2013). Financial Inclusion in Africa: An Overview. African Development Bank.

Klapper, L. (2014, May 2). Why are 75\% of the World's Poor Unbanked. Retrieved from http://live.worldbank.org: http://live.worldbank.org/qa-why-are-75-worlds-poorunbanked

Leora . (2014). Measuring Financial inclusion (Global Findex).

Love, I., \& Bruhn, M. (2009). The Economic Impact Of Banking The Unbanked: Evidence From Mexico. Policy Research Working Papers.

Lusardi, A. (2005). Financial Education and the Saving Behavior of African-American and Hispanic Households.

Maeshall. (2004). Financial institutions in disadvantaged areas: a comparative analysis of policies encouraging financial inclusion in Britain and the United States. Environment and Planning.

Micheal, S., \& Barr. (2002). Banking for the Unbanked. Law Quad.Notes 45,.

NL, K., NS, W., \& DR, A. (2002). Content analysis: review of methods and their applications in nutrition education.

OECD. (2011). OECD library.

Osaki, Y., \& Burhouse, S. (2011). 2011 FDIC National survey of Unbanked and Underbanked Households. FDIC.

Pasha, M. (2016). What Will It Take for Pakistan to Achieve Financial Inclusion? The World Bank.

Potter, \& Levine-Donnerstein, D. (1999). Rethinking validity and reliability in content analysis. Journal of Applied Communication research.

Rehman, A. H. (2007). Bank interest and Muslim society. Islamic Research Foundation International, Inc.

Shiekh, A. (2016, Sep). Will Banks Pull it Off. Baking on Digital Inclusion.

Soleda, M., Demirguc-Kunt , A., \& Beck, T. (2007). Banking Services for Everyone? Barriers to Bank Access and Use Around the World. JEL Classification.

The world bank. (2012, april 19). Three Quarters of The World's Poor Are "Unbanked". Retrieved from http://www.worldbank.org/en/news/feature/2012/04/19/three-quartersof-the-worlds-poor-are-unbanked 